\title{
The Effect of Visual Contextual Support and Glossary of Words on Guessing Meaning of New Vocabulary Items in English by Pre-university Male EFL Students
}

\author{
Kamal Nasrollahi \\ Department of English, Islamic Azad University, Urmia, Iran \\ Samran Daneshfar \\ Department of English Language and Literature, University of Zanjan, Zanjan, Iran
}

\begin{abstract}
The present study aims at investigating the impact of visual contextual support and Glossary of Words on EFL learners' vocabulary learning. For this purpose, a total number of 60 male pre-university students were randomly selected after administering the English proficiency test to assure the homogeneity of the participants. The learners were assigned to three homogeneous groups, 2 experimental groups, namely, visual contextual support and glossary of words and one control group to highlight the comparative purposes. During treatment, the first experimental group received a passage including new vocabulary items and visual contextual supports as treatment and the second experimental group received the same passage including new vocabulary items and the glossary of words as treatment. On the other hand, the control group received no treatment and they were just given the new vocabulary items of the same passages given to the experimental groups in order to guess the meaning of new words only by using their own vocabulary knowledge. To compare the probable differential impact of the study a pretest and posttest were applied to all three groups and the results of the tests were contrasted and analysed. For data analysis, the one-way ANOVA was administered for pretest and posttest. The results of the study demonstrated a significant improvement of vocabulary learning through utilizing visual contextual support in comparison to the glossary of words group and moreover than the control group.
\end{abstract}

Index Terms - glossary, visual contextual support, guessing meaning, vocabulary

\section{INTRODUCTION}

Vocabulary knowledge is very important in learning a language and is a prominent element in any language. It is also the component block of building up any given language. Vocabulary knowledge plays a crucial part in learning a language, in addition, it is an effective issue in achieving higher levels of proficiency in the target language (Boers $\&$ Lindstromberg, 2008), enhancing learners' communicative competence (McCrostie, 2007).

Considering vocabulary as an important part of a language, specific attention is paid to it in language teaching. From the more traditional grammar-translation method in which the focus was on memorizing a long list of vocabulary to the more recent methods in which the focus is on working actively on vocabulary, there has always been a number of strategies for vocabulary learning. Zhan-Xiang (2004) believes that words of a language are just like bricks of high buildings; despite being small pieces, they are necessary for the strength of the structure. Researchers now consider vocabulary as one of the most important components of language upon which effective communication relies (Oxford \& Scarella, 1994).

However, vocabulary was not given attention before the mid-1980s (Coday, 1997; Meara, 1995). Rivers (1983) states that the best method for learning vocabulary is not mere teaching but should be introduced, defined, and included through forms of activities. Further, she claims that language teachers need to encourage learners' attention in words, and they must help their students by directing them toward vocabulary learning and the methods of learning vocabulary.

The aim of this study is to provide English language learners and teachers with a succinct, conceptual framework of the effects of visual contextual support and glossary of words on guessing the meaning of new English vocabulary items among Pre-University Male students.

\section{BACKGROUND AND LITERATURE REVIEW}

\section{A. Vocabulary}

It has been known for a long time that vocabulary is an essential element of any language and all language learners quite well comprehend that without enough vocabulary knowledge their communication will be incomplete. 
Communication is not made when the interlocutors do not know and consequently cannot use the exact words and stops when people lack the needed vocabulary (Allen, 1983). Knowing a word is not an all or nothing phenomenon; it is a complex concept to define. According to Cronbach (1992, as cited in Mukoroli, 2011), learners should know both the general relationship between words and the different relationships including antonyms, synonyms, and collocations.

To individuals, knowing a word means having information about its meaning, connotations, spelling, derivations, collocations, frequency, pronunciation, syntactic constructions, the morphology and its semantic associates including synonyms, antonyms, etc. (Nagy \& Scott, 2000). According to Hulstjin et.al. (1996) knowing a vocabulary item is the ability to translate the word into the first language, discovers the correct definition, and paraphrase it in the target language.

Knowing good body of vocabulary can lead to communicative competence (McCrostie, 2007). When learners have a salient knowledge of vocabulary, they would improve their communication, that means speaking, listening, reading and writing skills. Also to have a higher vocabulary development, language learners can understand unknown words in a text and infer their meanings from contexts. Learners cannot produce and comprehend language without some vocabulary knowledge. Therefore, vocabulary knowledge is one of the central requirements of language acquisition and can be achieved through teachers' vocabulary teaching strategies (Ghezelseflou \& Seyedrezaei, 2015; Mukoroli, 2011). Since vocabulary knowledge paves the way to an adequate communication, it should be regarded a fundamental part of language learning (Wallace, 1982). Thus, teachers pay more attention to foreign language vocabulary acquisition (Zu, 2009).

However, some English L2 learners do not have this word knowledge, even for frequently occurring words and they face controversial issues throughout the L2 learning (Verhallen \& Schoonen, 1993). Richards (2001) emphasizes that "vocabulary knowledge consists of various dimensions which define the meaning of words" (p. 357). There is a distinction between knowing a word and using it. Knowing a word will not lead to using it in a variety of contexts (McCarthy, 1984). Ellis (1994) suggests that the knowledge aspect includes explicit learning; however, the use aspect includes implicit learning. Vocabulary learning strategies should include strategies for using and knowing a word.

\section{B. Vocabulary Learning Importance}

Vocabulary acquisition was underestimated by researchers, theorists, teachers and others involved in second language learning for many years. Schmitt (2000) holds that systematic work on vocabulary did not begin until the late twentieth century. The neglect and absence of vocabulary in teaching have been frequently addressed in the literature (Judd, 1978; Nunan, 1991; Zimmerman, 1997). Fortunately, after a growing number of experimental studies, the interest in vocabulary teaching increased and during the last two decades, vocabulary teaching has come to the heart of English language teaching (Ozgul \& Abdulkadir, 2012).

Second language acquisition researchers believe that in order to improve language skills which end up in an adequate communication, vocabulary is playing a fundamental role. (Ghezelseflou \& Seyedrezaei, 2015). Shahpari and Shamshiri (2014) state that learning vocabulary is an integral process for EFL learners to acquire proficiency and competency in the target language and it is the vital mean of accelerating fluency and accuracy. Furthermore, it is particularly effective in achieving higher levels of proficiency in the target language (Boers \& Lindstromberg, 2008).

On the importance of vocabulary in language learning, Krashen (1989) states that "a large vocabulary is of course, essential for mastery of language" (p. 4). Moreover, Rubin and Thompson (1994) point out that one cannot speak, read, or write a foreign language without knowing an amount of enough words. Vocabulary is at the heart of mastering a foreign language. Nation (2001) believes that a vast amount of vocabulary could be acquired with the help of vocabulary strategies and that the strategies prove useful for students of different levels. However, a number of researchers argue that a dearth of research concerning the field of vocabulary learning is apparent in the literature (Hunt \& Beglar, 2005) and that it is not yet clear which means of vocabulary learning is the most effective help to language learning (De Groot, 2006). Nowadays, it is taken for granted that vocabulary learning is one of the most important elements in the acquisition of both one's native language and a foreign language (Morra \& Camba, 2009). Since vocabulary learning in a second/foreign language is challenging and there is a need to overcome them, instructing vocabulary is quite essential for language teachers (Nation, 2001).

\section{Teaching Vocabulary in EFL}

Teaching and Learning vocabulary has been under an increasing importance by SLA researchers in the last two decades; moreover, several studies have confirmed that vocabulary knowledge plays an essential role in the L2 acquisition, and vocabulary instruction should be an integral part of language instruction. Nunan (1999) claims that, recently, teaching vocabulary has assumed its rightful place as a fundamentally important aspect of language development. This is due to the influence of comprehensive-based approaches to language development, the research efforts of influential applied linguists and the exciting possibilities opened up by the development of computer-based language corpora. In the following section, three main methods of teaching vocabulary are defined briefly.

D. Implicit vs. Explicit 
According to Hayati and Shahriari (2010), "methods of vocabulary learning are often debated in the literature: explicit methods (direct, often de-contextualized) and implicit methods (indirect, contextualized). Strong advocates on both sides of the debate are not hard to find" (p. 29).

Implicit learning refers to the lack of consciousness of the structure being learned. Rashidi and Ganbari (2006) define implicit learning by the "lack of consciousnesses in learning a specific structure to be learned" (p.115). Reber (1976), for example, defines implicit learning as "a primitive process of apprehending structures by attending to frequency cues" as opposed to "a more explicit process whereby various mnemonic, heuristic, and strategies are engaged to induce a representational system" (p. 93). Explicit learning means learning by direct communication of word meanings (Sonbul \& Schmitt, 2010). Explicit instruction involves "identifying the words learners need to know, presenting the word for the first time, elaborating word knowledge and developing fluency with known words" (Hunt \& Beglar, 2005).

\section{E. 2.3.2 Incidental vs. Intentional}

Huckin and Coady (1999) describe incidental learning as "a by-product, not the target of the main cognitive ability, reading" (p. 182). Yali (2010) declares intentional learning as "conscious vocabulary learning strategies and means of memorizing words" and incidental learning as learning through texts while doing activities unrelated to vocabulary. According to Ellis (1999), "intentional learning requires focal attention to be placed deliberately on the linguistic code (i.e., on form or form-meaning connections)," while "incidental learning requires attention to be placed on meaning (i.e., message content) but allows peripheral attention to be directed at form" (pp. 45-6).

\section{F. Teaching Vocabulary in Context}

Considering the prime attention to vocabulary learning and teaching strategies on various methods of vocabulary presentation and meaning guess (Gu \& Johnson, 1996), it is disappointing that most of the learners favour mechanical strategies such as repetition over deeper, more complex ones (Schmitt \& McCarthy, 1997; Lawson \& Hogben, 1996). According to Celce-Murcia and Rosensweig (1979), "there is a significant requirement for research over the vocabulary learning approaches applied by the language learners of different proficiency levels, with different levels of age, to guide the instructors toward more practical vocabulary teaching. Researchers (Palmberg, 1988) believe that new vocabulary should be taught in context.

The main reason for teaching vocabulary in context is authenticity. There are several strategies for teaching vocabulary including real objects, pictures, translation and etc. Using pictures to explain the meaning of new words is a method which is seen as one of the most valid ways of communicating the meaning of a word. Nation (2004) states that any ways of communicating meaning involve the changing of an idea into more observable form is likely to be misunderstood, and may not convey the exact concept of the word. Meanwhile, an advantage of using pictures is that learners see an example of the meaning and this may help them to remember the meaning of the word. If using pictures is combined with a verbal definition then there is the chance that dual encoding will occur (Paivio \& Desrochers, 1981).

One of the most useful semi-contextualizing methods for vocabulary learning is visual imagery. It makes a connection between a picture and a word. The theory behind this technique is that most learners can associate new information with the stored information in memory through meaningful visual images, thus learning gets more efficient. Visual imagery helps learners store information more efficiently than they could if they just used word lists. White (1998) believes that visual/textual enhancement can help L2 learning by attracting learners' attention to certain L2 features, and help them improve their false analyses of L2. Thus, according to Zoghi and Mirzaei (2014), "visual/ textual enhancement appears to affect learners' knowledge and performance in the second language, and it seems reasonable to expect language teachers and syllabus designers to make use of visual/ textual enhancement" (p. 34).

\section{G. Empirical Studies on Vocabulary}

In a study by Marcella $\mathrm{Hu}$ (2013), the effects of word exposures and contextual richness on the three aspects of vocabulary knowledge, orthography, form-meaning connection and grammatical functions were investigated. The results indicated that word frequency affected orthographical knowledge more than on the other two aspects, whereas contextual richness had a greater impact on form-meaning connections and grammatical functions. Moreover, Shoari and Farrokhi (2014) investigated the effect of graphic organizer strategy on improving Iranian EFL learners' vocabulary learning. A number of 50 students participated in two groups, an experimental that were taught new vocabulary items through graphic organizers in form of clusters and pictures, and the participants in the control group whose were taught the same items through traditional instruction. The results confirmed that graphic organizers were indeed conducive to L2 vocabulary learning by the learners.

An investigation of the impact of using two types of vocabulary contextualization; textual and visual, in teaching vocabulary was applied by Zoghi and Mirzaei (2014). Seventy students in pre-intermediate level aged from 14 to 30 participated in the study. Based on a Cambridge Placement Test of Vocabulary, learners were selected and divided into two groups of 35. The lexical items were taught to group 1 and group 2 through showing videos and written texts respectively. Results of the study illustrated the significant effect of visual contextualization teaching on learners' vocabulary acquisition more than those involved in reading written texts.

Accordingly, Zahedi and Abdi (2012) studied the effect of visual imagery on learners' vocabulary meaning guess. Pre-test and post-test were conducted to examine its effect. The findings indicated that the experimental group receiving 
visual imagery outperformed the control group in terms of English vocabulary meaning guess. Following this line of investigation, this study analyzed the extent to which teaching vocabulary through visual contextual support and glossary of words could enhance learners' vocabulary meaning guess.

\section{METHOD}

\section{A. Participants}

The participants were comprised of 60 pre-university L2 male students from a high school in Piran Shahr, Iran. Prior to the treatment, in order for group selection, the researcher selected 60 homogeneous participants from among 120 learners through an adapted version of the vocabulary-size test by Paul Nation. Then, the researcher assigned them into 2 experimental groups, namely, visual contextual support and glossary of words and one control group. Each class included 20 learners. The participants were within the age range of 16-18. All of the participants were Kurdish and able to speak Persian as their second language while studying English as their foreign language.

\section{B. Instrumentation}

To fulfil the purpose of this study the following instruments were used:

- An adapted version of vocabulary-size test by Paul Nation

- A Researcher-made pre-test of vocabulary

- A Researcher-made post-test of vocabulary

\section{Adapted Version of Vocabulary-size Test by Paul Nation}

An adapted version of the vocabulary-size test by Paul Nation including 60 words was administered to a sample similar to the main population at the beginning of the study to check the reliability of the test. The test was in multiplechoice format. Having collected the data, the researcher calculated the reliability of the test. Then, the same test was administered to the main participants for selecting homogeneous participants

\section{Researcher-made Pre-test and Post-test of Vocabulary}

A researcher-made test of vocabulary including 50 questions was administered to a sample similar to the main population check the reliability of the test. The test was in multiple-choice format. Having collected the data, the researcher calculated the reliability of the test. Then, the same test was administered to the main participants as the pretest. At the end of the treatment, the same test as the post-test of vocabulary was administered to the participants as well.

\section{E. Procedure}

At the outset of the study, three pre-university classes were selected in a high school in Piranshahr. Then, for the purpose of selecting homogeneous participants, the researcher used an adapted vocabulary size test by Nation and Beglar (2007) including 60 multiple-choice questions. The words chosen for the test were among the less frequent vocabulary items occurring in formal contexts, the meanings of which were to be guessed by learners based on the contextual clues provided for them. This was to make sure the meanings of words were not already known to them. Thus, this study had an experimental design. Then, a researcher-made vocabulary pre-test was administered to the participants. During the treatment, the experimental groups went through two forms of intervention, that is, one group was administered visual contextual support and the other one received the glossary of words in comparison to the control group with no treatment. At the end of the procedure, all three groups were exposed to post-test to see the probable impact of treatment on the experimental groups.

Before the test application, the researcher piloted the test with a group of subjects similar to those of the target sample to calculate the internal consistency of this test via Cronbach Alpha. Having made sure that the test was reliable, the researcher administered it to 120 subjects from which 60 subjects whose scores fell within one standard deviation above and below the mean were selected for the research. Then, the participants were randomly assigned to three groups of 20 learners, that is, two as experimental and one as control groups. To guarantee the homogeneity of the participants in both control and experimental groups, the researcher calculated a series of one-way ANOVAs to get the assurance that there is no meaningful difference between them. After ensuring that the three groups were homogeneous regarding vocabulary knowledge and that there was no significant difference among them, the next step was to launch the instructional procedure.

During the treatment period, the first experimental group received a passage including new vocabulary items and visual contextual supports as treatment and the second experimental group received the same passage including new vocabulary items and a glossary of words as treatment. However, the third class as the control group received no treatment and they were just given the new vocabulary items in the same passages given to the two previous classes in order to guess the meaning of new words only by using their own vocabulary knowledge. At the end of the treatment which lasted a month, the same researcher-made vocabulary pre-test was administered to learners as post-test to evaluate the effects of different kinds of treatment on learners' vocabulary enhancement.

In order to analyse the data obtained from post-test results and gauge the effect of different types of treatment on learners' vocabulary guessing ability enhancement, the researcher used a one-way ANOVA to: 
1) In the pre-test to establish homogeneity across the participants in three groups,

2) At the end of the study, that is, the post-test to figure out the possible impact of various treatment patterns

Additionally, post hoc comparisons using the Tukey HSD test were conducted in the post-test stage to find out where exactly the difference among the vocabulary teaching techniques existed.

\section{RESUlts}

As the researcher initiated data collection phase by giving the proficiency test of vocabulary to check for homogeneity of groups and single out the possible outliers, in what follows first the results of homogeneity analysis for the proficiency test results are presented.

In checking for the homogeneity of data distribution, first the researcher consulted the output of KolmogorovSmirnov and Shapiro-Wilk tests. Table I below indicates the descriptive statistics for proficiency test scores, and Table II illustrates the test of normality results. As is seen in Table II, the data do not enjoy normal distribution.

TABLE I.

DESCRIPTIVE STATISTICS FOR PROFICIENCY TEST SCORES

\begin{tabular}{|c|c|c|c|c|}
\hline \multicolumn{5}{|l|}{ Descriptives } \\
\hline & & & Statistic & Std. Error \\
\hline \multirow[t]{13}{*}{ Proficiency } & Mean & & 72.75 & .85317 \\
\hline & $95 \%$ Confidence Interval for Mean & Lower Bound & 71.04 & \\
\hline & & Upper Bound & 74.45 & \\
\hline & $5 \%$ Trimmed Mean & & 73.73 & \\
\hline & Median & & 74.00 & \\
\hline & Variance & & 47.31 & \\
\hline & Std. Deviation & & 6.87 & \\
\hline & Minimum & & 46.00 & \\
\hline & Maximum & & 80.00 & \\
\hline & Range & & 34.00 & \\
\hline & Interquartile Range & & 7.00 & \\
\hline & Skewness & & -2.511 & .297 \\
\hline & Kurtosis & & 7.267 & .586 \\
\hline
\end{tabular}

As revealed in Table I, the mean of proficiency test scores equals 74.45 , and the variance and standard deviation of the scores are 47.31 and 6.87 , respectively. Furthermore, the maximum score on the test is 80 and the minimum score is 46.

TABLE II.

TEST OF NORMALITY FOR PROFICIENCY TEST SCORES

\begin{tabular}{lllllll}
\hline Tests of Normality & \multicolumn{9}{l}{} \\
\hline & \multicolumn{1}{l}{ Kolmogorov-Smirnov ${ }^{\mathrm{a}}$} & Shapiro-Wilk & \\
\cline { 2 - 7 } & Statistic & Df & Sig. & Statistic & df & Sig. \\
\hline Proficiency & .268 & 65 & .000 & .711 & 65 & .000 \\
\hline a. Lilliefors Significance Correction & & & & & & \\
\hline
\end{tabular}

As it is seen in Table II, the proficiency test scores are not normally distributed $(p<.05)$. Fig. 1 , helps provide a better, more vivid illustration of the way the distribution of scores for proficiency test violates the conditions of normality.

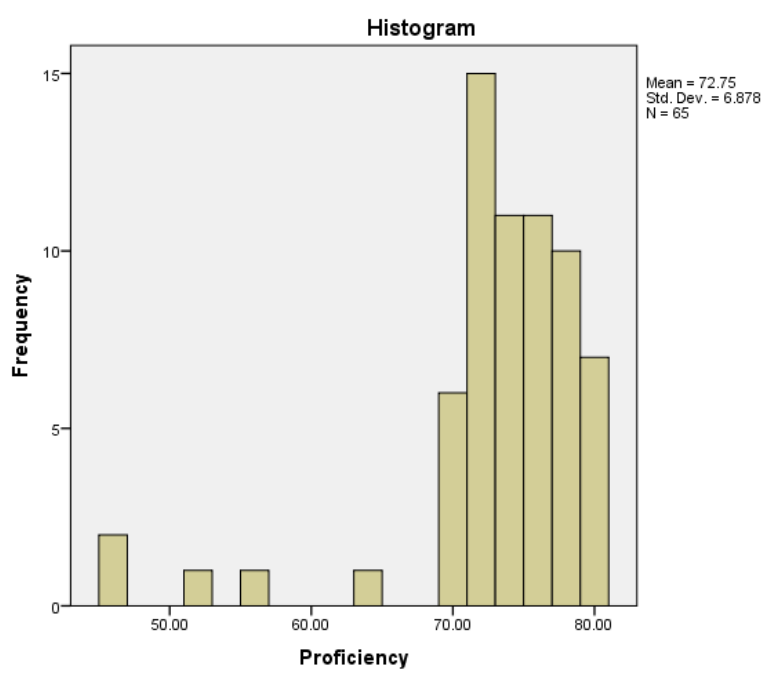

Figure1. The histogram for the distribution of proficiency test scores. 
The Boxplot below Fig. 2, further corroborates this finding and singles out the outliers and extreme outliers in the group.

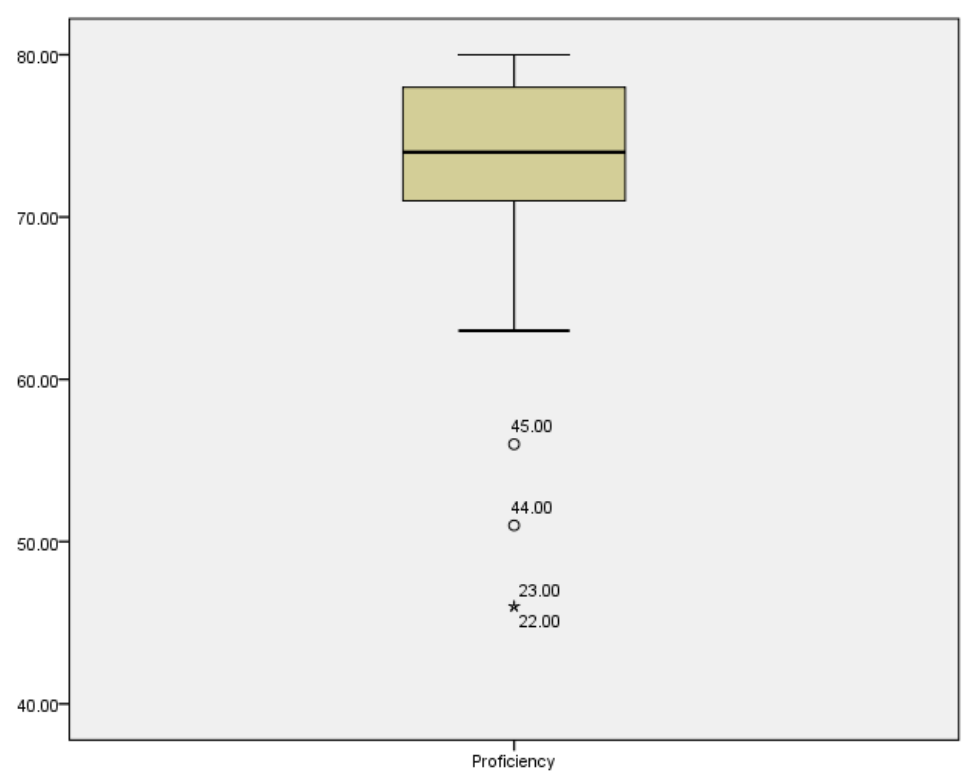

Figure 2. Boxplot showing the distribution of proficiency test scores.

\section{A. Data Analysis for Pretest Scores}

Running Kolmogorov-Smirnov test revealed that the pretest scores are normally distributed and hence parametric statistics were allowed to be used. Table III below shows the descriptive statistics for pretest scores, and Table IV illustrates the test of normality results. As is seen in Table IV, the data have normal distribution.

TABLE III.

DESCRIPTIVE STATISTICS FOR PRETEST SCORES

\begin{tabular}{|c|c|c|c|c|}
\hline \multicolumn{5}{|l|}{ Descriptives } \\
\hline & & & Statistic & Std. Error \\
\hline \multirow[t]{13}{*}{ Pretest Scores } & Mean & & 69.44 & .46637 \\
\hline & $\overline{95 \%}$ Confidence Interval for Mean & Lower Bound & 68.51 & \\
\hline & & Upper Bound & 70.37 & \\
\hline & 5\% Trimmed Mean & & 69.63 & \\
\hline & Median & & 70.00 & \\
\hline & Variance & & 13.70 & \\
\hline & Std. Deviation & & 3.70 & \\
\hline & Minimum & & 52.00 & \\
\hline & Maximum & & 75.00 & \\
\hline & Range & & 23.00 & \\
\hline & Interquartile Range & & 4.00 & \\
\hline & Skewness & & -1.630 & .302 \\
\hline & Kurtosis & & 6.551 & .595 \\
\hline
\end{tabular}

As revealed in Table III, the mean of pretest scores is 69.44 , and the variance and standard deviation of the scores are 13.70 and 3.70, respectively. Furthermore, the maximum and minimum scores on the test are 75 and 52, respectively.

TABLE IV.

TEST OF NORMALITY FOR PRETEST SCORES

\begin{tabular}{llll}
\hline \multicolumn{4}{c}{ TEST OF NORMALITY FOR PRETEST SCORES } \\
\cline { 2 - 4 } & \multicolumn{4}{l}{ Kolmogorov-Smirnov ${ }^{\mathrm{a}}$} \\
\cline { 2 - 4 } & Statistic & Df & Sig. \\
\hline Pretest Scores & .110 & 63 & .056 \\
\hline
\end{tabular}

As is seen in Table IV, the pretest scores are normally distributed ( $p>.05$ ); therefore, parametric statistics (one-way ANOVA) can be analyzed to compare the pretest means. Tables V through 4.7 list the descriptive statistics, Levene test results, and one-way ANOVA results, respectively. 
TABLE V.

DESCRIPTIVE STATISTICS FOR PRETEST SCORES

\begin{tabular}{|c|c|c|c|c|c|c|c|c|}
\hline \multicolumn{9}{|c|}{ Descriptives } \\
\hline \multicolumn{9}{|c|}{ Pretest Scores } \\
\hline & \multirow[b]{2}{*}{$\mathrm{N}$} & \multirow[b]{2}{*}{ Mean } & \multirow{2}{*}{$\begin{array}{l}\text { Std. } \\
\text { Deviation }\end{array}$} & \multirow[b]{2}{*}{ Std. Error } & \multicolumn{2}{|c|}{ 95\% Confidence Interval for Mean } & \multirow[b]{2}{*}{ Minimum } & \multirow[b]{2}{*}{ Maximum } \\
\hline & & & & & Lower Bound & Upper Bound & & \\
\hline Cont. & 21 & 69.80 & 2.67 & .58 & 68.59 & 71.02 & 65.00 & 75.00 \\
\hline Exp. 1 & 22 & 69.09 & 4.95 & 1.05 & 66.89 & 71.28 & 52.00 & 75.00 \\
\hline Exp. 2 & 20 & 69.45 & 3.11 & .69 & 67.98 & 70.91 & 65.00 & 75.00 \\
\hline Total & 63 & 69.44 & 3.70 & .46 & 68.51 & 70.37 & 52.00 & 75.00 \\
\hline
\end{tabular}

According to Table V, the mean scores for control, experimental one and experimental two groups are 69.80, 69.09, and 69.45, respectively and the standard deviations for these three groups of individuals equal 2.67, 4.95 and 3.11, respectively.

TABLE VI.

LEVENE TEST FOR PRETEST SCORES

\begin{tabular}{|c|c|c|c|}
\hline \multicolumn{4}{|c|}{ Test of Homogeneity of Variances } \\
\hline \multicolumn{4}{|l|}{ Pretest Scores } \\
\hline Levene Statistic & df1 & df2 & Sig. \\
\hline 1.685 & 2 & 60 & .194 \\
\hline
\end{tabular}

As Table VI reveals, the assumption of the homogeneity of variances is not violated $(p>.05)$.

TABLE VII

ONE-WAY ANOVA FOR PRETEST SCORES

\begin{tabular}{llllll}
\hline \multicolumn{7}{l}{ ANOVA } \\
\hline Pretest Scores & Sum of Squares & df & Mean Square & F & Sig. \\
\hline & 5.549 & 2 & 2.775 & .197 & .822 \\
\hline Between Groups & 844.006 & 60 & 14.067 & & \\
\hline Within Groups & 849.556 & 62 & & & \\
\hline Total & & & & & \\
\hline
\end{tabular}

As is seen in Table VII, no significant difference is witnessed among the three groups $(p>.05)$ and hence the desired outcome for the researcher is obtained, because no significant difference among the three groups of learners exists prior to treatment.

\section{B. Data Analysis for Posttest Scores}

At the outset, to check for the normal distribution of posttest scores, Kolmogorov-Smirnov test was run the results of which are shown in Table IX. Table VIII below shows the descriptive statistics for posttest scores.

TABLE VIII.

DESCRIPTIVE STATISTICS FOR POSTTEST SCORES

\begin{tabular}{|c|c|c|c|c|}
\hline \multicolumn{5}{|l|}{ Descriptives } \\
\hline & & & Statistic & Std. Error \\
\hline \multirow[t]{13}{*}{ Posttest Scores } & Mean & & 79.66 & 1.12 \\
\hline & $95 \%$ Confidence Interval for Mean & Lower Bound & 77.41 & \\
\hline & & Upper Bound & 81.91 & \\
\hline & 5\% Trimmed Mean & & 79.72 & \\
\hline & Median & & 80.00 & \\
\hline & $\underline{\text { Variance }}$ & & 79.80 & \\
\hline & Std. Deviation & & 8.93 & \\
\hline & Minimum & & 64.00 & \\
\hline & Maximum & & 95.00 & \\
\hline & Range & & 31.00 & \\
\hline & Interquartile Range & & 17.00 & \\
\hline & Skewness & & -.106 & .302 \\
\hline & Kurtosis & & -1.170 & .595 \\
\hline
\end{tabular}

As revealed in Table VIII, the mean of pretest scores is 79.66, and the variance and standard deviation of the scores are 79.80 and 8.93, respectively. Furthermore, the maximum and minimum scores on the test are 95 and 64 , respectively.

TABLE IX.

EST OF NORMALITY FOR POSTTEST SCORES

\begin{tabular}{llll}
\hline & \multicolumn{4}{l}{ Kolmogorov-Smirnov ${ }^{\mathrm{a}}$} \\
\cline { 2 - 4 } & Statistic & df & Sig. \\
\hline Posttest Scores & .106 & 63 & .075 \\
\hline
\end{tabular}


As Table IX illustrates, the posttest scores have not violated the conditions for normal distribution $(p>.05)$; thus, parametric statistics (one-way ANOVA) can be again utilized to compare the posttest means. Tables X through XII list the descriptive statistics, Levene test results, and one-way ANOVA results for posttest scores, respectively.

TABLE X.

DESCRIPTIVE STATISTICS FOR POSTTEST SCORES

\begin{tabular}{|c|c|c|c|c|c|c|c|c|}
\hline \multicolumn{9}{|c|}{ Descriptives } \\
\hline \multicolumn{9}{|c|}{ Posttest Scores } \\
\hline & \multirow[b]{2}{*}{$\mathrm{N}$} & \multirow[b]{2}{*}{ Mean } & \multirow[b]{2}{*}{ Std. Deviation } & \multirow[b]{2}{*}{ Std. Error } & \multicolumn{2}{|c|}{ 95\% Confidence Interval for Mean } & \multirow[b]{2}{*}{ Minimum } & \multirow[b]{2}{*}{ Maximum } \\
\hline & & & & & Lower Bound & Upper Bound & & \\
\hline Cont. & 21 & 69.00 & 2.89 & .63 & 67.68 & 70.31 & 64.00 & 74.00 \\
\hline Exp. 1 & 22 & 80.36 & 2.10 & .44 & 79.43 & 81.29 & 77.00 & 85.00 \\
\hline Exp. 2 & 20 & 90.10 & 2.40 & .53 & 88.97 & 91.22 & 86.00 & 95.00 \\
\hline Total & 63 & 79.66 & 8.93 & 1.12 & 77.41 & 81.91 & 64.00 & 95.00 \\
\hline
\end{tabular}

According to Table X, the mean posttest scores for control, experimental one and experimental two groups are 69.00, 80.36, and 90.10, respectively and the standard deviations for these three groups of individuals equal $2.89,2.10$ and 2.40 , respectively.

TABLE XI.

LEVENE TEST FOR POSTTEST SCORES

\begin{tabular}{llll}
\hline Test of Homogeneity of Variances \\
\begin{tabular}{llll}
\hline Posttest Scores & & \\
\hline Levene Statistic & df1 & df2 & Sig. \\
\hline 901 & 2 & 60 & .412 \\
\hline
\end{tabular}
\end{tabular}

As Table XI reveals, the assumption of the homogeneity of variances is not violated $(p>.05)$.

TABLE XII.

ONE-WAY ANOVA FOR POSTTEST SCORES

\begin{tabular}{llllll}
\hline ANOVA & \multicolumn{7}{l}{} \\
\hline Posttest Scores & Sum of Squares & df & Mean Square & F & Sig. \\
\hline Between Groups & 4577.109 & 2 & 2288.555 & 370.226 & .000 \\
\hline Within Groups & 370.891 & 60 & 6.182 & & \\
\hline Total & 4948.000 & 62 & & & \\
\hline
\end{tabular}

According to Table XII, a significant amount of difference exists among the three groups $(p<.05)$ and hence the null hypothesis of the research can be rejected. Furthermore, as Tukey HSD results (Table XII) indicate, all three groups have performed significantly differently from one another.

TABLE XIII.

TUKEY HSD RESULTS FOR POSTTEST SCORES

\begin{tabular}{|c|c|c|c|c|c|c|}
\hline \multicolumn{7}{|c|}{ Multiple Comparisons } \\
\hline \multicolumn{7}{|c|}{ Dependent Variable: Postest Scores } \\
\hline \multicolumn{7}{|c|}{ Tukey HSD } \\
\hline \multirow[b]{2}{*}{ (I) Group } & \multirow[b]{2}{*}{ (J) Group } & \multirow[b]{2}{*}{ Mean Difference (I-J) } & \multirow[b]{2}{*}{ Std. Error } & \multirow[b]{2}{*}{ Sig. } & \multicolumn{2}{|c|}{ 95\% Confidence Interval } \\
\hline & & & & & Lower Bound & Upper Bound \\
\hline \multirow[t]{2}{*}{ Cont. } & Exp. 1 & $-11.36364^{*}$ & .75851 & .000 & -13.1865 & -9.5408 \\
\hline & $\overline{\text { Exp. } 2}$ & $-21.10000^{*}$ & .77681 & .000 & -22.9668 & -19.2332 \\
\hline \multirow[t]{2}{*}{ Exp. 1} & Cont. & $11.36364^{*}$ & .75851 & .000 & 9.5408 & 13.1865 \\
\hline & Exp. 2 & $-9.73636^{*}$ & .76815 & .000 & -11.5824 & -7.8903 \\
\hline \multirow[t]{2}{*}{ Exp. 2} & Cont. & $21.10000^{*}$ & .77681 & .000 & 19.2332 & 22.9668 \\
\hline & Exp. 1 & $9.73636^{*}$ & .76815 & .000 & 7.8903 & 11.5824 \\
\hline
\end{tabular}

Fig. 3, below displays the mean Plots for posttest scores. 


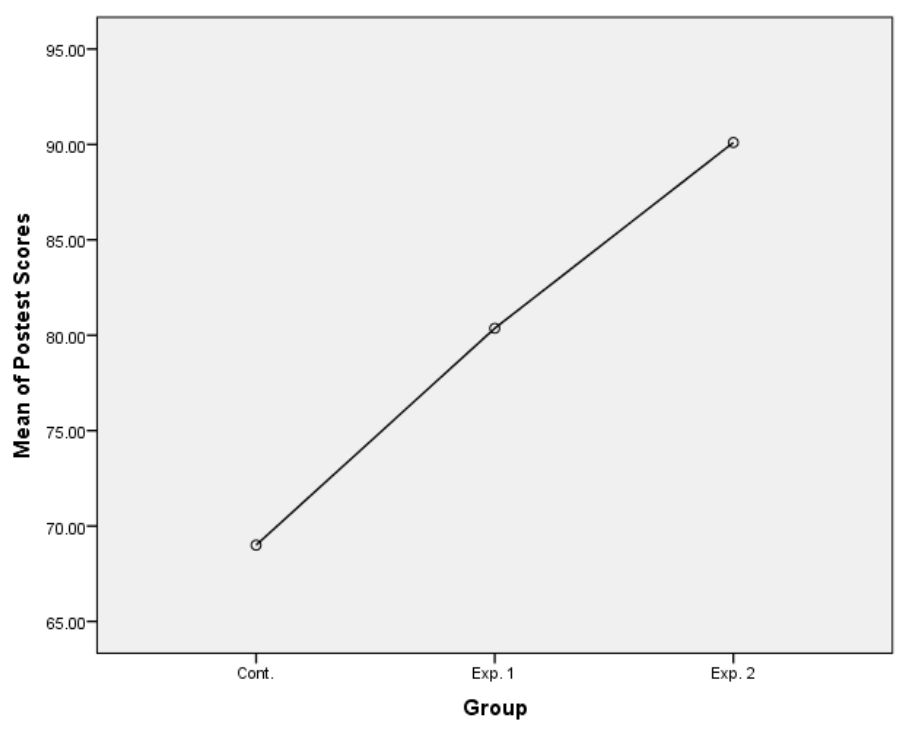

Figure 3. Mean plots for posttest scores.

\section{DISCUSSION}

The results of the study revealed a significant difference between the vocabulary mean scores of the first experimental (visual contextual support) and the second experimental group (glossary of words) and the control group (i.e., the vocabulary mean score of the first experimental group was significantly more than the other two groups). Thus, the researcher concludes that using visual contextual support and glossary of words have significantly increased the vocabulary scores of the experimental groups.

Regarding the research question, that is, whether teaching vocabulary using visual contextual support and glossary of words enhances meaning guess of vocabulary, it was answered satisfactorily in the light of the quantitative data collected from researcher-made vocabulary test administered before and after the treatment sessions. It was explored that using visual contextual support had the most influential effect on EFL learners' ability to guess the meaning of vocabulary compared with the second experimental group and control one. Regarding the second experimental group, the findings indicated that glossary of words was more effective in enhancing EFL learners' guessing ability in comparison to the control groups. The analysis of the quantitative data revealed that the participants who received vocabulary instruction in visual contextual support and glossary of words retained more words than those who were not given treatment. It may support the claims of scholars (e.g., Ciftçi \& Uster, 2009; Sadeghi \& Farzizadeh, 2013;) who believe that visual contextual support serves as a memory aid. Results showed that learners who learned the vocabulary items through visual contextualization enhanced their vocabulary acquisition more than those involved in reading written texts.

The results of the present study indicate that the participants in the first experimental group (visual contextual support) outperformed the ones in the second experimental group and the control group. The underlying reason could be that the learners in the experimental group were taught how through visual contextual support whereas, the learners in the control group were taught the routine program authorized by the authorities of the institute. Thus, vocabulary teaching via visual contextual support technique assisted learners to keep the vocabulary items in their minds more efficiently.

A quick survey of the results would indicate that visual contextual support has improved and expanded vocabulary knowledge of the participants of this study to a great deal. Moreover, to corroborate what has hitherto been discussed, the results of the present study confirm that those learners who were required to use and learn vocabulary items via visual contextual support could both use and improve their vocabulary knowledge more efficiently. To put it briefly, this study has revealed that teaching vocabulary via visual contextual support is a useful technique which is definitely contributing to the EFL learners' expansion of vocabulary meaning guess.

\section{CONCLUSION}

Vocabulary is the core of any existing language, the issue of vocabulary acquisition, as well as meaning guess, is the interest of many researchers. Following this line of investigation, this study analysed the extent to which visual contextual support and glossary of words could enhance learners' vocabulary meaning guess.

The primary aim of the present research was to investigate whether visual contextual support and glossary of words had any effect on guessing the meaning of new vocabulary items of pre-university male EFL students. In other words, this study investigated to what extent visual contextual support and glossary of words could develop EFL learners' vocabulary guess when compared with teaching vocabulary with traditional techniques. 
To conclude, this study revealed that using visual contextual support for teaching vocabulary develops students' vocabulary awareness. In other words, it showed that students, when taught vocabulary in visual contextual support, retain more words than they do when they are taught vocabulary as isolated items. Consequently, findings of the study indicated that visual contextual support was very effective in enhancing EFL learners' vocabulary meaning guess. In other words, learners in the group receiving visual contextual support outperformed their counterparts in both experimental and control groups in terms of developing their vocabulary meaning guess. This finding has supported the previous studies on the visual contextual support such as Ciftçi and Uster (2009), Sadeghi and Farzizadeh (2013) and Zahedi and Abdi (2012) whose results emphasize its positive effect on foreign language vocabulary learning.

\section{Pedagogical ImPlications OF THE StUdy}

This study has revealed that teaching vocabulary via visual contextual support is using techniques which are definitely contributing to the EFL learners' expansion of guessing vocabulary meaning. The findings of this study may be of benefit to EFL teachers and EFL teaching in general. Teachers can make use of teaching vocabulary through that visual contextual support as a teaching device in their classes. Teachers of English could be encouraged to spare some more classroom time for this type of training in their classes and to assign more importance to the application of certain learning strategies in vocabulary development in order to make vocabulary learning process more effective and more meaningful for the students.

As a teacher is also a researcher, the teachers can also benefit from this study to do their own research to find more effective ways of teaching and learning vocabulary. This study is just one step to this end and many other steps should be taken to make learning easier for language learners.

Using visual contextual support can be beneficial in teaching vocabulary because it can create new contexts for the students and learning would be more interesting. When students receive vocabulary instruction in visual contextual support, they can increase deeper knowledge of vocabulary which would help them to use the vocabulary in appropriate situations. Visual contextual support can create a more preparatory pretext to achieve a deeper knowledge of vocabulary. They can increase the amount of understanding and reduce the number of difficulties in understanding abstract vocabulary.

Based on the results, language teachers should keep in mind the fact that students have to be aware of what "knowing a word" means. They should know that just knowing the definition or mother tongue equivalent of a word does not mean that they know that word. For using a word in a context, students should be encouraged to develop a system of vocabulary learning which will lead them to be independent vocabulary learners.

What is more, the visual contextual support identified in this study can be used in teacher training courses, especially for novice teachers. Also, based on the findings of this study, syllabus and material developers can also make use of this technique to teach vocabulary.

\section{SUGGESTIONS FOR FURTHER RESEARCH}

The main focus of this study was to investigate the effect of visual contextual support and glossary of words on Iranian EFL learners' vocabulary meaning guess over time. The researcher does not claim that this study is the ultimate proof of the efficacy of visual contextual support. Indeed, other studies could be conducted to reject or accept this hypothesis. With respect to the aforementioned limitations of the study, the following points deserve further exploration in the future.

This study focused on Iranian EFL pre-university learners. Other similar research could be done on other language proficiency levels, too. This study was limited to 16-18-year-old learners. Interested researchers can conduct a similar study on older or younger learners. One, even, can make use of a comparative study to compare the effect of visual contextual support on children and adult learners. In this study, the subjects were just males. However, other comparative studies on both male and female learners can be done. The subjects of this study were Iranian EFL learners. Other research can be done in the ESL setting. If possible, even a comparative study can be conducted to compare the effect of visual contextual support in EFL \& ESL settings.

\section{REFERENCES}

[1] Allen, V. F. (1983). Techniques in teaching vocabulary. England: Oxford University Press.

[2] Boers, F., \& Lindstromberg, S. (2008). How cognitive linguistics can foster effective vocabulary teaching. In F. Boers \& S. Lindstromberg (Eds.), Applications of cognitive linguistics: Cognitive linguistic Approaches to teaching vocabulary and phraseology (pp.1-61). Berlin: Mouton de Gruyter.

[3] Celce Murcia, M., \& Rosensweigh, F. (1979). Teaching vocabulary in the ESL classroom. In M. Celce Murcia. \& L. McIntosh (Eds.), Teaching English as a second or foreign language (241-257). Massachusetts: Newbury House.

[4] Ciftci, H., \& Uster, S. (2009). A comparative analysis of teaching vocabulary in context and by definition. Procedia-Social and Behavioral Sciences, 1(1), 1568-1572.

[5] Coady, J. (1997). L2 vocabulary acquisition through extensive reading. In J. Coady \& T. Huckin (Eds.), Second language vocabulary acquisition (pp. 225-237). Cambridge: Cambridge University Press. 
[6] De Groot, A. M. B. (2006). Effects of stimulus characteristics and background music on foreign language vocabulary learning and forgetting. Language Learning, 56(3), 463-506.

[7] Ellis, R. (1994). The study of second language acquisition. Oxford: Oxford University Press.

[8] Ellis, R. (1999). Learning a second language through interaction. Amsterdam: John Benjamin's Publishing Company.

[9] Ghezelseflou, M., \& Seyedrezaei, S. H. (2015). An investigation on the impact of teaching vocabulary through collocations on the vocabulary retention of EFL learners. International Journal of Basic Sciences \& Applied Research, 4(3), 162-170.

[10] Gu, Y., \& Johnson, R. K. (1996). Vocabulary learning strategies and language learning outcomes. Language Learning, 46(6), 643-679.

[11] Hayati, M., \& Shahriari, A. (2010). The impact of L1 equivalents versus context on vocabulary recall of pre-university EFL students. The journal of Teaching Language Skills, 2, 27-51.

[12] Huckin, T., \& Coady, J. (1999). Incidental vocabulary acquisition in a second language. Studies in Second Language Acquisition, 21(2), 181-193.

[13] Hulstijn, J; Hollander, M; \& Greidanus, T. (1996). Incidental vocabulary learning by advanced foreign language students: The influence of marginal glosses, dictionary use, and reoccurrence of unknown words. The Modern Language Journal, 80(3), 327339.

[14] Hunt, A. \& Beglar, D. (2005). A framework for developing EFL reading vocabulary. Reading in a Foreign Language, 17, 2359.

[15] Judd, E. (1978). Vocabulary teaching and TESOL: A need for re-evaluation of existing assumptions. TESOL Quarterly, 12, 7176.

[16] Krashen, S. D. (1989). We acquire vocabulary and spelling by reading: Additional evidence for the input hypothesis. Modern language journal, 73(4), 44-46.

[17] Lawson, M. J., \& Hogben, D. (1996). The vocabulary-learning strategies of foreign-language students. Language Learning, 46(1), 101-135.

[18] Marcella Hu, H-Ch. (2013). The effects of word frequency and contextual types on vocabulary acquisition from extensive reading: A case study. Journal of Language Teaching and Research, 4(3), 487-495.

[19] McCarthy, M. (1984). Vocabulary. Oxford: Oxford University Press.

[20] McCrostie, J. (2007). Examining learner vocabulary notebooks. ELT Journal: English Language Teachers Journal, 61(3), 246255.

[21] Meara, P. (1995). The classical research in L2 vocabulary acquisition. In G. Anderman \& M. Rogers (Eds.), Words, words, words: The translator and the language learner (pp. 27-37), Clevedon, UK: Multilingual Matters.

[22] Morra, S., \& Camba, R. (2009). Vocabulary learning in primary school children: Working memory and long-term memory components. Journal of Experimental Child Psychology, 104, 156-178.

[23] Mukoroli, J. (2011). Effective vocabulary teaching strategies for the English for academic purposes ESL classroom (Unpublished MA thesis). Brattleboro, Vermont.

[24] Nagy, W., \& Scott, J. (2000). Vocabulary processes. In R. Barr, P. Mosenthal, P. D. Pearson, \& M. Kamil (Eds.), Handbook of reading research (pp. 269-284). Hillsdale, NJ: Lawrence Erlbaum Associates.

[25] Nation, I. S. P. (2001). Learning vocabulary in another language. Cambridge: Cambridge University Press.

[26] Nation, I. S. P. and Beglar, D. (2007). A Vocabulary Size Test. The Language Teachers, 31(7), 9-13.

[27] Nunan, D. (1991). Language teaching methodology. London: Prentice Hall.

[28] Nunan, D. (1999). Second language teaching and learning. Boston: Heinle \& Heinle.

[29] Oxford, R. L., \& Scarella, R. C. (1994). Second language vocabulary learning among adults: State of the art in vocabulary instruction. System, 22, 231-243.

[30] Ozgul, B., \& Abdulkadir, C. (2012). Teaching vocabulary through collocations in EFL classes: The case of Turkey. International Journal of Research Studies in Language Learning, 1(1), 21-32.

[31] Paivio, A., \& Desrochers, A. (1981). Mnemonic techniques in second-language learning. In Nation, P. (Ed.), Learning vocabulary in another language (pp. 85). Cambridge: Cambridge University Press.

[32] Palmberg, R. (1988). Computer games and foreign-language vocabulary learning. ELT Journal, 42(4), $247-252$.

[33] Rashidi, N \& Ganbari Adivi, A. (2006). Incidental vocabulary learning through comprehension focused reading of short stories. Journal of English Language Teaching and Learning, 53(217), 111-129.

[34] Reber, A. (1976). Implicit learning of synthetic: The role of instructional set. Journal of Experimental Psychology: Human Learning and Memory, 2, 88-94.

[35] Richards, J. C. \& Rodgers, T. S. (2001). Approaches and methods in language teaching. Cambridge: Cambridge University Press.

[36] Rivers, W. (1983). Communicating naturally in a second language. Cambridge: Cambridge University Press.

[37] Rubin, J. \& Thompson, I. (1994). How to be a more successful language learner. Boston, MA: Heinle \& Heinle Publishers.

[38] Sadeghi, K., \& Farzizadeh, B. (2013). The effect of visually-supported vocabulary instruction on beginner EFL learners' vocabulary gain. MEXTESOL Journal, 37(1), 1-12.

[39] Schmitt, N. (2000). Vocabulary in language teaching. Cambridge: Cambridge University Press.

[40] Schmitt, N., \& McCarthy, M. (1997). Vocabulary: Description, acquisition and pedagogy. Cambridge: Cambridge University Press.

[41] Shahpari, N., \& Shamshiri, H. R. (2014). Intentional vs. incidental vocabulary learning \& Iranian EFL learners' retention. Enjoy Teaching Journal, 2(3), 1-11.

[42] Shoari, E., \& Farrokhi, F. (2014). The effect of graphic organizer strategy on improving Iranian EFL learners' vocabulary learning. Iranian Journal of Research in ELT, 1, 71-83.

[43] Sonbul, S., \& Schmitt, N. (2010). Direct teaching of vocabulary after reading: is it worth the effort? ELT Journal, 64(3), 253260. 
[44] Verhallen, M., \& Schoonen, R. (1993). Vocabulary knowledge of monolingual and bilingual children. Applied Linguistics, 14, 344-363.

[45] Wallace, M. J. (1982). Teaching vocabulary. London: Heinemann Educational Books Limited.

[46] White, J. (1998). Getting the learners' attention. In C. Doughty \& J. Williams (Eds.), Focus on form in classroom second language acquisition (pp. 85-113). Cambridge: Cambridge University Press.

[47] Yali, G. (2010). L2 vocabulary acquisition through reading: Incidental learning and intentional learning. Chinese Journal of Applied Linguistics, 33(1), 74-93.

[48] Zahedi, Y., \& Abdi, M. (2012). The impact of imagery strategy on EFL learners' vocabulary learning. Procedia - Social and Behavioral Sciences, 69, 2264-2272.

[49] Zhan-Xiang, M. (2004). The necessity of intensifying English vocabulary in the remote minority area college English teaching. Asian EFL journals, 6(2), 25-31.

[50] Zimmerman, C. B. (1997). Historical trends in second language vocabulary acquisition. In J. Coady, \& T. Huckin, Second language vocabulary acquisition (pp. 5-19). Cambridge: Cambridge University Press.

[51] Zoghi, M., \& Mirzaei M. (2014). A comparative study of textual and visual contextualization on Iranian EFL learners' vocabulary learning. International Journal of Basic and Applied Science, 2(3), 31-40.

[52] Zu, F. (2009). Using lexical approach to teach vocabulary.US-China Foreign Language, 7(8), 44-47.

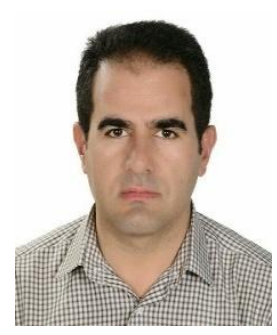

Kamal Nasrollahi was born in Naghadeh, Iran, in 1978. He registered at the University of Urumia in 2000 and received his BA in English Language and Literature in 2004. Just after graduation, he started teaching English to language learners aged from 6 to 40 years old. In 2016 he got his MA in English Language Teaching from Azad University of Tehran (the branch of Urumia). Overall, he has been teaching English to various age groups since 2004 and at present, he is managing his own Language Institute in Piranshahr and is simultaneously teaching the language in question. His biggest interest is to study "English for Specific Purposes (ESP)" and "Psychology of English Language Learning/Teaching".

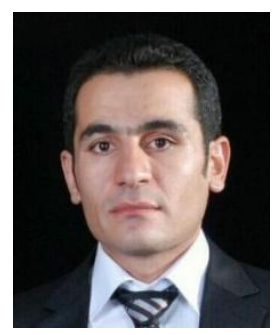

Samran Daneshfar was born in Piran Shahr, Iran. He received a B.A. in English Language and Literature from Urmia University-Iran (2009) and he is an MA graduate in English Language Teaching (TEFL) from the University of Zanjan-Iran (2014). He is currently an experienced EFL teacher in Ministry of Education in Piran Shahr. He is teaching at junior secondary school. His areas of interest are applied linguistics, Teaching English to Speakers of Other Languages (TESOL), the Sociocultural Theory and Dynamic Assessment in second language. 